\title{
A guidingkatéter szerepe a thrombusaspiráció hatékonyságának növelésében: Esetismertetés
}

\author{
Kákonyi Kornél, Katona András, Ungi Imre
}

\author{
Szegedi Tudományegyetem, Általános Orvostudományi Kar, Belgyógyászati Klinika, \\ Invazív Kardiológiai Részleg, Szeged \\ Levelezési cím: \\ Dr. Kákonyi Kornél, SZTE Szent-Györgyi Albert Klinikai Központ, Belgyógyászati Klinika, Invazív Kardiológiai Részleg, \\ 6725 Szeged, Semmelweis u. 8. E-mail: kakonyikornelmano@gmail.com
}

A rutinszerű thrombusaspiráció szerepe vitatott az ST-elevációs miokardiális infarktus ellátásában. A legfrissebb randomizált kontrollált klinikai vizsgálatok (TASTE [Thrombus Aspiration in ST-Elevation Myocardial Infarction in Scandinavia] és TOTAL [Trial of Routine Aspiration Thrombectomy With PCI Versus PCI Alone in Patients With STEMI]) alapján a rutinszerü alkalmazás nem javasolt. Ugyanakkor látható, nagy volumenű thrombus esetén az aspiráció fontos eszköz az intervenciós kardiológus kezében primer $\mathrm{PCl}$ során.

A 64 éves férfi beteget inferior STEMI miatt észleltük osztályunkon. Koronarográfia során a jobb koronária posterolateralis ágának stenttrombózisa igazolódott. Számos alkalommal végeztünk dedikált 6F-es aspirációs katéterrel thrombusaspirációt, de egy a cruxhoz közeli nagy thrombusreziduumot ezzel nem tudtunk eltávolítani. A guidingkatéterrel mélyre kanülálva sikeresen végeztünk thrombusaspirációt, majd a bifurkációban culotte stentelést végeztünk. Zárófelvételen TIMI 3 anterográd áramlás volt látható.

A 29 éves férfi inferior STEMI miatt érkezett osztályunkra. A koronarográfia a jobb koronária horizontális szakaszán igazolt trombotikus okklúziót. Dedikált 6F-es aspirációs katéterrel, több alkalommal történt aspiráció ellenére jelentős mennyiségü thrombusreziduum maradt az érben. A 6F-es felvezetőkatétert a jobb koronária horizontális szakaszába vezettük, majd stabil drótpozíció mellett, a guidingkatéterrel aspiráltunk. Kontroll angiográfia során szignifikáns szükület nem volt látható TIMI 3 áramlással, így stentimplantációt nem végeztünk.

A guidingkatéterrel történő thrombusaspiráció, tekintettel a proximális érszakasz sérülésének kockázatára, nem veszélytelen manőver, azonban kellő gyakorlattal végezve a nagyobb belső átmérő miatt jelentősen hatékonyabb a dedikált katéterekkel végzett aspirációnál.

Kulcsszavak: thrombusaspiráció, guidingkatéter, STEMI, PCI

\section{The role of the guiding catheter to increas the efficiency of thrombus aspiration}

The role of routine thrombus aspiration during the management of ST-segment-elevation myocardial infarction is debatable. According to recent randomized controlled clinical trials (TASTE [Thrombus Aspiration in ST-Elevation Myocardial Infarction in Scandinavia] and TOTAL [Trial of Routine Aspiration Thrombectomy With PCI Versus PCI Alone in Patients With STEMI]) the routine use is not recommended. Nevertheless, in case of large, visible thrombus aspiration is an important option for interventional cardiologists during primary $\mathrm{PCl}$.

64-year-old male patient was diagnosed with inferior STEMI. Coronary angiography revealed stent thrombosis of the right coronary artery posterolateral branch. We aspirated several times with $6 \mathrm{~F}$ aspiration catheter but a huge thrombus near the crux was not being retractable. We performed deep intubation with $6 \mathrm{~F}$ guiding catheter and aspirated the thrombus. Culotte $\mathrm{PCl}$ was done in the bifurcation. Angiographic result was good, antegrade TIMI 3 flow.

29 year-old male patient was diagnosed with inferior STEMI. Coronary angiography revealed occlusion of distal segment of the right coronary artery. We aspirated several times with $6 \mathrm{~F}$ aspiration catheter but huge thrombus residuum was not aspirateable. The $6 \mathrm{~F}$ guiding catheter was introduced into the distal segment of the right coronary artery and aspirated the thrombus. Control coronary angiography verified no significant coronary artery stenosis and TIMI 3 flow therefore stent implantation was not performed.

Although thrombus aspiration with a guiding catheter is not harmless technique, because of the risk of injury of the proximal segment of the vessel, but doing with a great routine it is more effective than aspiration with dedicated catheters, because of bigger inner diameter.

Keywords: thrombus aspiration, guiding catheter, STEMI, PCI 


\section{Bevezetés}

A thrombusaspiráció (TA) az ST-elevációs miokardiális infarktus (STEMI) primer PCl-vel történő ellátásának fontos lépése bizonyos esetekben. A TA célja a thrombus burden és a disztális embolizáció mértékének csökkentése, ezzel mérsékelve a no-reflow és a stenttrombózis esélyét. A 2008-ban publikált TAPAS-vizsgálatban rutinszerüen alkalmazott TA az 1 éves utánkövetés során szignifikáns mértékben csökkentette a halálozást (1). Ezzel szemben a legfrissebb nagy esetszámú randomizált kontrollált klinikai vizsgálatok, a TASTE és a TOTAL a rutinszerü TA előnyeit nem igazolták $(2,3)$, a TOTAL-vizsgálat betegeiben a rutinszerüen végzett TA növelte a stroke kockázatát (4). A legfrissebb ajánlások szerint a rutinszerủen végzett TA nem javasolt (5). A nagy thrombus burden a mortalitás független prediktora (3), így a TA fontos eszköz a trombotikus léziók kezelésében. Az alábbi két eset bemutatásával arra szeretnénk felhívni a figyelmet, hogy egy egyszerü, költségmentes eljárással hogyan tudjuk jelentősen fokozni a TA hatékonyságát a kockázat érdemi növekedése nélkül.

\section{1. eset}

A 64 éves férfi beteget inferior STEMI miatt észleltük egy napja fennálló mellkasi fájdalommal és hipotóniával. Anamnézisében jobb koronária (JC) posterolatera- lis $(\mathrm{PL})$ ág (2010), r. descendens anterior (RDA) és r. circumflexus (CX) (2011) PCI szerepelt, továbbá 2015ben akut koronáriaszindróma kapcsán JC $\mathrm{PCl}$ történt. A jobb arteria radialis felől végzett koronarográfia során a JC PL ágának stenttrombózisa igazolódott. $6 \mathrm{~F}$ JR 4,0 felvezető katéterrel kanüláltuk az eret, majd BMW (Abbott Laboratories, Chicago, USA) dróttal passzáltuk az okklúziót. Számos alkalommal végeztünk aspirációt Eliminate (Terumo corp., Tokyo, Japan) aspirációs katéterrel, de egy a cruxhoz közeli nagy thrombusreziduumot ezzel nem tudtunk eltávolítani. A guidingkatétert mélyre kanülálva a JC-PL-ágba vezettük, majd folyamatos aspiráció mellett eltávolítottuk a betegből az eszközt a vezetődróttal együtt. Tekintettel a korábban végig stentelt JC-re, illetve a guidingkatéter ellenállás nélküli levezethetőségére, a proximális érszakasz sérülésétől nem tartottunk. A kontrollfelvételen thrombus már nem volt látható, a katéterből nagy mennyiségü thrombus ürült. A bifurkációban culotte stentelést végeztünk $3 \times 48$ és $3 \times 19$ mm-es gyógyszerkibocsátó stentekkel, jó angiográfiás eredménnyel, TIMI 3 anterográd áramlással (1. ábra).

\section{2. eset}

A 29 éves férfi inferior STEMI miatt került felvételre, osztályunkra egyórás panaszokkal. Anamnézisében lényegi belszervi betegség nem szerepelt, rizikófaktorai közül dohányzás emelendő ki. Koronarográfia során a JC hori-
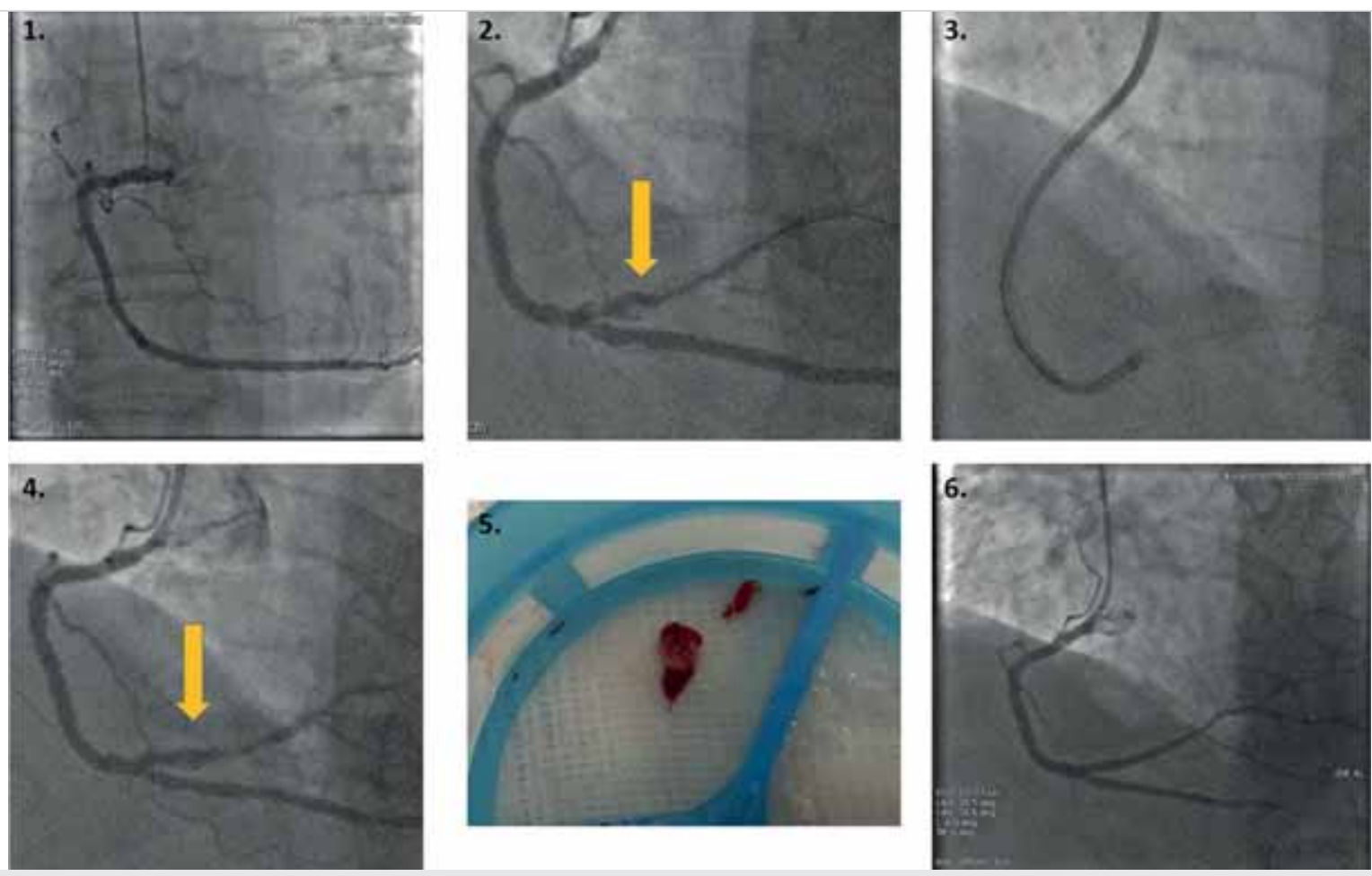

1. ÁBRA. 1. A jobb koronária instent trombotikus okklúziója. 2.Thrombusreziduum (nyíl) a jobb koronária posterolateralis ágában. 3. Mélyrekanülálással végzett aspiráció az RCA PL-ágából. 4. Kontroll angiográfia a sikeres thrombusaspiráció után, a nyíl a thrombus helyét mutatja. 5. Az aspirált trombus. 6. Culotte-stentelés után TIMI 3 anterográd flow 


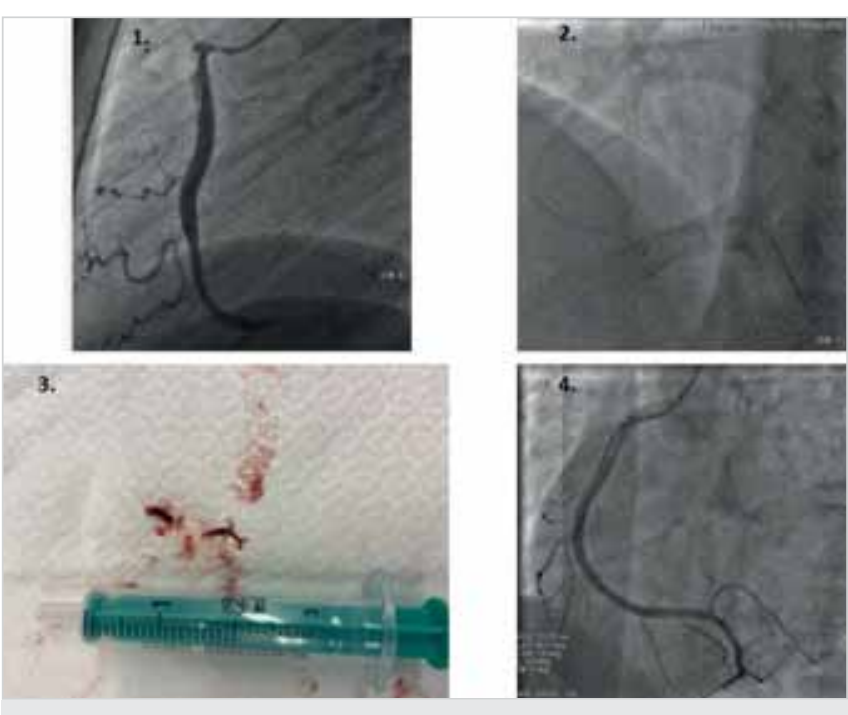

2. ÁBRA. 1. A jobb koronária a horizontális szakaszán okkludált. 2. Mélyrekanülálással végzett aspiráció az RCA horizontális szakaszából. 3. Az aspirált thrombusok. 4. Záróangiográfia TIMI 3 áramlással stentimplantáció nélkül

zontális szakaszának trombotikus okklúziója igazolódott. A JC szájadékát 6F JR 4,0 katéterrel kanüláltuk, majd a JC disztális részébe BMW-drótot vezettünk. Eliminate aspirációs katéterrel, számos alkalommal aspiráltunk, de ezek után jelentős mennyiségű thrombusreziduum maradt az érben. A guidingkatétert mélyre kanülálva a cruxig vezettük, majd az „Y” adapter nyomás felöli portjára fecskendőt helyeztünk, folyamatos szívás mellett a katétert a proximális szakaszba húztuk a drótpozíció megőrzése mellett. A katéter visszahúzása mellett az áramlás a fecskendőben megindult, jelentős mennyiségü thrombust távolítottunk el a fecskendőből. A katétert alaposan visszavéreztettük, az „Y” adaptert átöblítettük és a nyomásgörbét ellenőriztük. Intrakoronáriás Gp IIb/IIla-blokkoló, adenozin és nitroglicerin adása után a kontroll angiográfia során szignifikáns szükület, disszekció nem volt látható TIMI 3 áramlással, így stentimplantációt nem végeztünk (2. ábra).

\section{Megbeszélés}

A thrombectomia jelenleg elterjedt, egyedüli módja a dedikált katéterekkel történő manuális aspiráció. A forgalomban lévő aspirációs katéterek 6 és 7F-es guidingkatéterekkel kompatibilisek. Ezek szívóportjának belső átmérője jelentős mértékben limitálja a beszívható vérrög maximális méretét. Emiatt a thrombus vagy fragmentálódik, és egyes darabjai eltávolíthatók, mások embóliát okozhatnak, vagy az egészben eltávolított thrombus a katéter hegyén „függeszkedve” távolítható el. Az utóbbi lehetőség azzal a veszéllyel jár, hogy egyes pontokon a thrombus vagy egyes darabjai leszakadnak és paradox koronária vagy szisztémás embolizációt okoznak. Feltehető, hogy részben ez a limitáció felelős a vizsgálatok során tapasztalt eltérő és gyakran elégtelen eredményekért az angiográfiás és klinikai végpontok tekintetében. A biztonságosan eltávolítható vérrög térfogatának és összmennyiségének elvi maximuma oly módon érhető el, ha a guidingkatéterrel végeznénk az aspirációt. Ennek elvi előnye, hogy ugyanazon szívóerő mellett nagyobb mennyiségű thrombus távolítható el az érből. A guidingkatéter nagyobb belső átmérőjéből eredően az alvadékot nagyobb darabokban vagy akár egyben is beszívhatja a lumenbe, szemben a dedikált 6 és 7F-es eszközökkel, amelyek hatékonyságának és biztonságának korlátait fent már említettük.

A guidingkatéterrel végzett TA esetén tehát az aspiráció hatékonysága és biztonsága is nagyobb, ennek ellenére technikai korlátai miatt nem terjedt el a rutinszerű TA-eszközeként. A guidingkatéterrel történő aspiráció korlátja, hogy a katéter levezetése csak bizonyos esetekben kivitelezhető manőver. Hipopláziás erekben nem lehetséges, továbbá merev, meszes erek tortuozitása és jelentős proximális ateroszklerózis, szignifikáns szükület is kontraindikációt képez az ér sérülésének veszélye miatt. $A z$ esetbemutatásban szereplő mindkét betegünkben a JC-ből távolítottunk el thrombust guidingkatéter segítségével. A JC mélyre kanülálása esetén az operatőr a katétert horális forgatás, gyengéd tolás és húzás mellett vezeti az érbe. Amenynyiben ez nem elegendő, az érbe „buddy wire” vezethető, vagy akár az extenziós katéterek levezetéséhez használatos disztális „anchor”, illetve „inchworm” technikák is alkalmazhatók. A túlzott erőltetés kerülendő a proximális érszakasz sérülésének elkerülésének céljából. Amikor a katéter a thrombust eléri és „wedge” pozícióba kerül, fecskendőt csatlakoztatunk az „Y”-hoz és folyamatos szívás mellett a koronária proximális szakaszába húzzuk az eszközt. Ha a proximális érszakaszba érkezéskor a katétert a thrombus nem obstruálja, azaz a fecskendőbe könnyedén aspirálunk vért, további, a guidingkatéter ürtartalmát többszörösen meghaladó mennyiségű vért szívunk le. A katéter visszavéreztetése után meggyőződünk az artériás nyomásgörbe formájáról, hogy a következő angiográfia ne okozhasson embolizációt. Amennyiben a fecskendőbe vért szívni nem tudunk a visszahúzáskor, úgy a katétert folyamatos szívás mellett eltávolítjuk. Ebben az esetben a katéter thrombus általi okklúziója valószínűsíthető. $A z$ „Y”-ra csatlakoztatott szívóeszköz során az „Y” bevezető portján levegő kerülhet a guidingkatéterbe, így a hosszas visszavéreztetés a légembólia elkerülése céljából is szükséges. A beavatkozás potenciális veszélye a guidingkatéter végén lebegő farokthrombus embóliája, ami azonban a nagy átmérőjü guidingkatéterrel történő aspiráció esetén lényegesen ritkább jelenség, mint kisebb átmérőjü és szűkebb végnyílású dedikált aspirációs katéterekkel. Fent bemutatott eseteinkben egy alkalommal sem tapasztaltuk cerebrális vagy perifériás embólia jeleit. 


\section{Következtetések}

A guidingkatéterrel történő thrombusaspiráció nem veszélytelen manőver, azonban kellő gyakorlattal végezve a nagyobb belső átmérő miatt jelentősen hatékonyabb a dedikált katéterekkel végzett aspirációnál. Eseteink tanulsága, hogy dedikált katéterrel nem kielégítő eredményü TA esetén a guidingkatéterrel végzett thrombuseltávolítás biztonságos és hatékony „bailout” eljárás.

\section{Nyilatkozat}

A szerzők kijelentik, hogy a közlemény megírásával kapcsolatban nem áll fenn velük szemben pénzügyi vagy egyéb lényeges összeütközés, összeférhetetlenségi ok, amely befolyásolhatja a közleményben bemutatott eredményeket, az abból levont következtetéseket vagy azok értelmezését.

\section{Irodalom}

1. Vlaar PJ, Svilaas T, van der Horst IC, et al. Cardiac death and reinfarction after 1 year in the Thrombus Aspiration during Percutaneous coronary intervention in Acute myocardial infarc- tion Study (TAPAS): a 1-year follow-up study. Lancet 2008; 371: 1915-1920. DOI: 10.1016/S0140-6736(08)60833-8

2. Frobert O, Lagerqvist B, Gudnason T, et al. Thrombus Aspiration in ST-Elevation myocardial infarction in Scandinavia (TASTE trial): a multicenter, prospective, randomized, controlled clinical registry trial based on the Swedish Angiography and Angioplasty Registry (SCAAR) platform: study design and rationale. Am Heart J 2010; 160: 1042-1048. DOI: 10.1016/j.ahj.2010.08.040

3. Jolly SS, Cairns JA, Lavi S, et al. Thrombus Aspiration in Patients With High Thrombus Burden in the TOTAL Trial. J Am Coll Cardiol 2018; 72: 1589-96. DOI: 10.1016/j.jacc.2018.07.047

4. Jolly SS, Cairns JA, Yusuf S, et al. Stroke in the TOTAL trial: a randomized trial of routine thrombectomy vs. percutaneous coronary intervention alone in ST elevation myocardial infarction. Eur Heart J 2015; 36: 2364-72. DOI: 10.1093/eurheartj/ehv296

5. Ibanez B, James S, Agewall S, et al. 2017 ESC Guidelines for the management of acute myocardial infarction in patients presenting with ST-segment elevation. Eur Heart J 2018; 39: 119-177. DOI: 10.1093/eurheartj/ehx393

6. Hara $\mathrm{H}$, Nakamura $\mathrm{M}$, Komatsu $\mathrm{H}$, et al. Comparison of the in vitro performance of 6 and 7 French aspiration catheters. Eurointerv 2007; 2: 487-492. DOI: 10.4244/EIJV2I4A86

\section{Levél a szerkesztőnek}

\section{Igen Tisztelt Szerkesztőség!}

Tomcsányi J, Jánosi I, Szakács L. Trimetazidin prolong hatásossága különböző életkorokban az ONECAPS-vizsgálat alapján Cardiologia Hungarica 2020; 50: 206-208 (1) dolgozatukban idézték az Orvosi Hetilapban megjelent metaanalízisünket (2). Köszönjük, hogy munkánk felkeltette a szerzők érdeklődését és ennek hatására kiegészítették az ONECAPS-tanulmány eredményeit (3). Eredetileg a korábban trimetazidint már szedő és a kezelést még nem használó betegek aránya fel lett ugyan tüntetve, de a trimetazidin prolong hatására bekövetkező heti anginaszám és sublingualis nitroglicerin-fogyasztás változása a két csoportban külön-külön nem, csak összesítve került közlésre. Köszönjük azt is, hogy felfigyeltek arra, hogy munkánkban összefüggést találtunk a trimetazidinkezelés hasznossága és a fiatalabb életkor között. A következőt írtuk: „Új megállapításunk az, hogy a rendelkezésre álló tanulmányok alapján a trimetazidinkezelés a kiszerelési formától és a dózistól ( $3 \times 20$ mg IR - $2 \times 35 \mathrm{mg} \mathrm{MR} \mathrm{-1 \times 80} \mathrm{mg} \mathrm{prolong)} \mathrm{függetlenül} \mathrm{statisztikailag} \mathrm{azonos} \mathrm{mértékben} \mathrm{csökkenti} \mathrm{CCS-ben} \mathrm{a} \mathrm{heti} \mathrm{anginaszámot}$ és sublingualis nitroglicerin-fogyasztást, továbbá a súlyosabb állapotú, fiatalabb beteg kezelésének klinikai haszna a legnagyobb.” (2). Felhívtuk a figyelmet metaanalízisünk korlátaira is: „Elemzésünk legföbb korlátja az, hogy a bevont vizsgálatok tervezése és a mindenkori időpontban az ajánlások által előírt és alkalmazott kezelés eltér egymástól.” (2). Véleményünk szerint az antianginás kezelés haemodinamikai és metabolikus alapokon nyugszik és eredményeink szerint mennél hamarabb (v.ö. mennél fiatalabb korban) érdemes bevezetni a trimetazidin bármely kiszerelési formájának adását.

Ezek után sajnáljuk, hogy a dolgozatban eredményeinket a szövegkörnyezetből kiragadva idézték. Sajnáljuk, hogy nem adták meg a statisztikai elemzés módszereit (valamilyen párosított teszt, vagy regressziós módszer) és az egyes csoportok közötti eltérések szignifikancia-szintjét. Sajnáljuk, hogy nem vették észre azt, hogy a bemutatott ábrákban a hatás változását jelző egyenesek meredekségei különbözőek, vagy akár metszik is egymást. Sajnáljuk, hogy azt sugallták, a metaanalízisbe nem megfelelően válogattuk be a tanulmányokat. Valóban nem végeztünk utólagos kozmetikázást, az eredeti beválasztási szabályoknak megfelelően válogattuk be a munkákat, mint ahogyan azt a korábbi metaanalíziseket elvégző kutatók is tették. Végül sajnáljuk azt is, hogy hibásan idézték a szerzőket, „Nagy VL, Herald Z” helyett helyesen Herold Zoltánt kellett volna írni. Budapest, 2020. VII. 29.

\section{Tisztelettel: Nagy Viktor László és Herold Zoltán}

Irodalom

1. Tomcsányi J, Jánosi I, Szakács L. Trimetazidin prolong hatásossága különbözö életkorokban az ONECAPS-vizsgálat alapján Cardiologia Hungarica 2020; 50: 206-208

2. Nagy VL, Herold Z. Clinical effect of various trimetazidine formulations in chronic coronary syndrome. An updated systemic review and meta - analysis. (A különféle trimetazidinkészítmények klinikai hatása stabil anginával járó krónikus koszorúér-szindrómában. Frissített módszeres áttekintés és metaanalízis.) Orv Hetil. 2020;161:611-622.

3. Tomcsányi J, Szakács L. Effectiveness of trimetazidine prolong in stable coronary artery disease. Multicenter, prospective, observational study, ONECAPS study. (Stabil coronaria betegség kezelésére alkalmazott trimetazidin prolong hatásosságának vizsgálata. Multicentrikus, prospektív, obszervációs, nyilt klinikai vizsgálat, ONECAPS- vizsgálat.) Orv Hetil. 2018;159:1549-1555. 